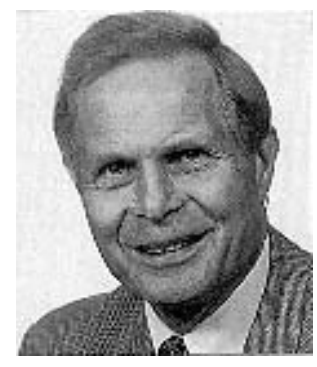

Uolevi Kantanen

\title{
MITEN MITATA \\ HENKILÖSTÖKOULUTUKSEN HYÖTYÄ?
}

\section{Koulutushankkeet kilpailevat organisaatioissa muiden investointi- suunnitelmien kanssa. Koulutuksen hyödyn osoittaminen ja sen vertaaminen esimerkiksi laiteinvestoinnin hyötyyn on osoittautunut käytännössa tarpeelliseksi. Toisin sanoen koulutukseltakin odotetaan taloudellisia perusteluita.}

Organisaatioiden henkilöstölleen järjestämästä koulutuksesta on runsaat 50 prosenttia yksityissektorin ja loput julkishallinnon koulutusta. Molemmissa tapauksissa on ruvettu yhä useammin kyselemään, miten organisaatio hyötyy järjestämästään koulutuksesta.

Henkilöstökoulutus katsotaan investoinniksi, sijoitukseksi henkiseen pääomaan. Organisaatioissa koulutuksen vaikutuksia tarkastellaan näin ollen järjestäjän taloudellisen hyödyn näkökulmasta. Avainasioita ovat koulutuksen vaikuttavuus, tuottavuus, tuloksellisuus, tehokkuus ja taloudellisuus. Koulutusinvestointeja on kannattavuudeltaan pystyttävä vertaamaan toisiinsa ja muihin investointeihin.

\section{TARKASTELUKULMA VAIKUTTAA TUTKIMUKSEEN}

Henkilöstökoulutuksen vaikutuksia järjestäjän näkökulmasta on tutkittu maassamme varsin vähän. Eräänä syynä tähän on se, että tutkijat ja henkilöstökoulutuksesta päättävät eivät puhu edes samaa kieltä. Mikäli tutkimuksen kohdeyleisönä pidetään koulutuksen päätöksentekijöitä, tutkimus on raportoitava selkeästi ja ytimekkäästi taloudellisin käsittein. Tekstin on oltava painavaa, mutta ei raskasta.

Tieteellisistä raporteista tutut monikymmensanaiset erikoissanastolla kyllästetyt virkkeet eivät sovi henkilöstökoulutusta koskevien raporttien kieleksi. Pragmaattiset paradigmat eivät ole relevantteja, jopa evaluointi ja reflektiivisyys ovat eskapismia. Moni koulutuspäällikkö on saanut kuulla koulutusesityksiä tehdessään: "Esitä se suomeksi! Mitä se merkitsee rahassa?” Työelämän edustajien mielestä numeroin esitettävä materiaali on nopeasti omaksuttavaa ja tehokasta. Tutkimustuloksina keskiarvot keskihajontoineen ovat useimmiten riittävät ja havainnolliset. 
Tutkija joutuu pohtimaan, voiko koulutuksen vaikutuksia ilmoittaa markkoina tai onko monimutkaisten asioiden pelkistäminen numeroiksi liian pinnallistavaa ja yksinkertaistavaa? Vastaheittona voi esittää, eikö oikeansuuntainen, vaikka vain pinnallinen, tieto ole parempaa kuin käyttämättä jäävä tieto? Henkilöstökoulutusta koskevat tutkimukset vaikuttavat rahan haaskaukselta, ellei niiden tuloksia käytetä hyväksi koulutuksen kehittämisessä. Luokkaan "hyvä tietää" kuuluvaa informaatiota liikkuu työpaikoilla aivan liikaa.

Koulutuksen järjestäjät odottavat henkilöstökoulutusta koskevilta vaikuttavuustuloksilta yleistettävyyttä. Tämä puolestaan johtaa määrälliseen tutkimusotteeseen. Mikäli henkilöstökoulutuksen vaikuttavuutta pohdittaisiin yksittäisen oppijan näkökulmasta tai haluttaisiin lisätä ymmärrystä oppimisprosessista, kasvatustieteessä suosiossa oleva laadullinen tutkimusote olisi sopivampi. Usein voidaan yhdistellä laadullista ja määrällistä tutkimustapaa, mutta pyrittäessä käytäntöä hyödyttäviin tuloksiin on pidettävä huolta tulosten yleistettävyydestä.

Raportoinnin ymmärrettävyyden ja tulosten yleistettävyyden vaatimusten lisäksi tutkimuksen on sisällettävä tulosten käyttäjille hyödyllistä tietoa. Henkilöstökoulutuksen vaikuttavuustutkimuksessa tulosten odotetaan antavan tietoa investoinnin taloudellisesta hyödystä.

\section{INVESTOINTIEN TALOUDELLISESTA PERUSTELEMISESTA}

Koulutushankkeet kilpailevat yrityksissä toteutusjärjestyksestä muiden investointisuunnitelmien kanssa. Koulutuksen hyödyn osoittaminen ja sen vertaaminen esimerkiksi laiteinvestoinnin hyötyyn on käytännössä osoittautunut tarpeelliseksi. Esimerkiksi koulutusta koskevassa EU:n Valkoisessa kirjassa (1995) kehotetaan kohtelemaan aineellisia ja koulutukseen liittyviä investointeja samalla tavalla. Toisin sanoen koulutusinvestoinneiltakin odotetaan taloudellisia perusteluita.
Taloudellisten perustelujen puuttuessa on moni hyvä koulutushanke jäänyt toteutumatta, toisaalta organisaatiot ovat maksaneet paljon hyödyttömästä koulutuksesta. Kun henkilöstökoulutukselle ei ole ollut taloudellisia mittareita, koulutusinvestointien perustelu ollut usein sattumanvaraista tai muuhun, kuin taloudellisiin laskelmiin perustuvaa. Eräs syy siihen, miksi yrityksissä ei ole vakavammin paneuduttu koulutusinvestointien perusteluihin, on koulutuskustannusten pieni osuus (koulutusajan palkka mukaanlukien $2 . .3 \%$ ) palkkamenoista.

Investointien taloudelliselle perustelulle on ominaista, että eriaikaiset menot ja tulot on saatava keskenään vertailukelpoisiksi. Tällöin on tärkeää tietää, milloin menot ja tulot lankeavat ja mikä on rahan hinta eri aikoina, eli millä kertoimella menot ja tulot muunnetaan keskenään vertailukelpoisiksi. Mitä suurempi on investointien aikajänne, sitä enemmän investointien laskentaan liittyy epävarmuutta.

Sijoitustoiminnassa on lähes aina vaihtoehtoja. Investointien suunnittelu onkin vaihtoehtojen hakemista ja niiden keskinäistä vertailua. Suunniteltaessa ja vertailtaessa joudutaan määrittelemään, millä laskentakorolla investoinnin tavoitetuotto ilmaistaan. Hyvässä investointilaskelmassa on esitetty myös, millä todennäköisyydellä tuotto saavutetaan.

On suositeltavaa käyttää henkilöstökoulutuksessa samoja investointien perustelumenetelmiä kuin muissakin investoinneissa. Koulutusinvestointeihin sopivat nykyarvomenetelmä tai investoinnin sisäisen korkokannan menetelmä tai molemmat yhdessä toistensa täydentäjinä.

Edellä esiteltyjä menetelmiä yksinkertaisemmalla tavalla ja käytännön tarpeita varten usein riittävällä tarkkuudella saadaan investointien tuotto laskemalla tuloksen ja sidotun pääoman suhde eli ROI (Return on Investment). Koulutusinvestoinneissa se voidaan laskea yksinkertaisesti jakamalla investoinnin hyödyt sen kustannuksilla, jolloin saadaan investoinnin tuottoaste. 
Mikäli ei ole saatavilla kaikkia edellämainituissa menetelmissä tarvittavia tietoja, eivät keinot suinkaan lopu, mutta koulutusinvestoinnin arvonmäärittelyssä on tyydyttävä yksinkertaisempaan ja suurpiirteisempään tapaan. Mm. Monteau (1987) suosittelee keskittymistä kriittisten tietojen tunnistamiseen $\mathrm{ja}$ niiden tutkimiseen. Hänen mukaansa koulutusohjelman kustannushyöty -analyysissa voidaan yksinkertaisesti laskea kustannuksiksi kaikki laskut ja hyödyiksi kaikki tulot. Kustannukset vähennetään tuloista vuosittain koulutuksen vaikutuksen ajalta. Laskutoimitusten summa eri vuosilta osoittaa investoinnin kokonaistuoton.

\section{KOULUTUSINVESTOINNEISSA TARVITTAVIA PERUSTIETOJA}

Kun koulutuksen vaikuttavuutta tutkitaan taloudellisin periaattein toimivan organisaation näkökulmasta, tarkastelu ohjautuu taloudellisen hyödyn määrittelyyn. Esimerkiksi Brinkerhoff (1991) on pelkistänyt henkilöstön kehittämisen logiikan seuraavasti: henkilöstöllä on tiedoissa, taidoissa tai asenteissa puutteita, joita voidaan korjata koulutuksella. Koulutuksen jälkeen henkilöstö toimii uusin valmiuksin ja investointi maksaa itsensä takaisin sijoittajalle (organisaatiolle).

Koulutusta järjestävän vastuuhenkilön olisi tärkeää tietää millaista koulutusta, kuinka paljon ja kenelle sitä olisi järjestettävä sijoitetun pääoman tuoton maksimoimiseksi. Tätä ensi ajattelulla mahdottoman vaikealta tuntuvaa haastetta voi lähestyä vaiheittain pilkkomalla haaste osaongelmiin. Kaikessa koulutuksessa ongelmia ei voida ratkaista yksinkertaisin keinoin. Monessa tapauksessa koulutuksen hyöty voidaan kuitenkin laskea investointisuunnittelussa vaadittavalla tarkkuudella. Ensin määritellään hyvän henkilöstökoulutuksen tunnukset, ja sitten pyritään järjestämään koulutus ko. tunnusten viitoittamana. Käytetäänhän henkilöstöhallinnossa muitakin yleisesti hyväksyttyjä tunnuslukuja.

\section{Lähtökohtana suomalaisen henkilöstökoulutuksen kartoitus}

Tavoitetilan ja nykytilan määrittely esitetään usein periaatteellisena lähtökohtana koulutustarpeen toteamisessa. Kehittämistarpeet saadaan niiden erotuksesta. Seuraavassa kuvataan erästä tapausta suomalaisen henkilöstökoulutuksen tavoitteellisten ominaisuuksien ja koulutuksen nykytilan määrittelyssä (Kantanen 1996).

Maassamme oli tehty ennen kyseistä kartoitusta henkilöstökoulutuksesta valtakunnan tasolla vain määrällisiä selvityksiä. Koulutuksen laatua ei oltu selvitetty.

Tavoitteena oli saada samalla kertaa yleistettävää tietoa henkilöstökoulutuksen menestystekijöistä ja toteutetun koulutuksen ominaisuuksista. Toisaalta selvityksessä saatavien tietojen avulla oli tavoitteena kehittää menestystekijöitä hyväksi käyttävä malli koulutusinvestointien taloudelliseksi perustelemiseksi.

Kartoitus tehtiin kirjekyselynä 1994. Siinä henkilöstökoulutuksen asiantuntijat määrittelivät tuloksellisen ja toteutuvan koulutuksen ominaisuuksia. Asiantuntijakyselyyn vastasi kaikkiaan 170 henkilöä. Toisaalta myös koulutuksen käyttäjät $(\mathrm{N}=340)$ määrittelivät omissa organisaatioissaan toteutuvan koulutuksen ominaisuuksia.

\section{Tuloksellisen koulutuksen menestystekijät ja toteutuvan koulutuksen yleiskuva}

Kartoituksissa 80 väittämään saadut vastaukset yhdisteltiin kymmeneksi hypoteettiseksi tuloksellisen koulutuksen menestystekijäksi. Menestystekijät oli muodostettu käytännön kokemuksen pohjalta niistä asioista, joita kysellään koulutuksessa olleilta. Väittämät oli puolestaan muodostettu henkilöstökoulutukseen käytännössä usein liitetyistä toteamuksista. Menestystekijät saivat tärkeysjärjestyksensä väittämiin annettujen vastausten keskiarvojen mukaan. 
Tärkeimmäksi menestystekijäksi nousi odotetusti koulutuksen liittyminen organisaation toimintaan ja johtamiseen. Ero esimiesten tukeen, koulutustulosten seurantaan, opetukseen ja motivaatioon oli kuitenkin vähäinen. Vähemmän tärkeiksi menestystekijöiksi osoittautuivat kyseessä olevassa tutkimuksessa koulutuksen hyödyntäminen, oppimateriaalit ja yleisjärjestelyt. Kun tutkimuksessa kartoitettiin koulutuksen menestystekijöitä, on selvää, etteivät viimeksimainitutkaan tekijät suinkaan osoittautuneet merkityksettömiksi.

Tuloksellisen koulutuksen menestystekijöiden lisäksi tutkimuksessa saatiin kartoitettua suomalaisen henkilöstökoulutuksen yleiskuva. Toteutunutta koulutusta koskeva kartoitus osoitti järjestetyssä koulutuksessa puutteita verrattaessa sitä tavoitteena pidettävään tulokselliseen koulutukseen. Koulutuksen asiantuntijoiden ja koulutuksen käyttäjien mielipiteet toteutuvan koulutuksen ominaisuuksista olivat jokseenkin yhdenmukaiset.

Molemmat mainitut ryhmät arvioivat koulutuksen sisäisten asioiden toteutuvan kohtuullisen hyvin. Arvioituja sisäisiä asioita olivat $\mathrm{mm}$. selkeät tavoitteet, opetus, opetusmenetelmät ja materiaalit. Koulutusprosessi siis hallittiin käytäntöä tyydyttävällä tavalla. Parannettavaa oli koulutuksen ulkoisissa tekijöissä, kuten koulutuksen liittymisessä organisaation johtamiseen ja toimintaan, kurssien oppien hyödyntämisessä ja esimiesten tuessa. Rahan arvoinen kysymys kuuluu siis: "Miten löydämme oikeat koulutusaibeet ja koulutettavat sekä miten esimiehet saadaan tukemaan koulutusta?"

\section{Koulutuksen rakennemallit}

Selvittelyä jatkettiin tekemällä menestystekijöistä tuloksellisen koulutuksen hypoteettisia rakennemalleja. Niitä testattiin ja kehitettiin faktori- ja rakenneanalyysien (LISREL) avulla. Kehitettyyn seitsemän tekijän malliin sisältyvät seuraavat tuloksellisen henkilöstökoulutuksen vaikuttavuustekijät: koulutuksen liittyminen organisaation toimintaan ja johtamiseen, koulutukseen osallistuvan henkilöstön omaehtoi- suus ja motivoituneisuus, oppien hyödyntäminen työssä, esimiesten tuki, koulutustulosten seuranta, koulutuksen laatu (tavoitteet, menetelmät, opetus) ja oppimateriaalit.

Tutkimuksessa kehitetty toinen malli, kuuden tekijän malli, on samanlainen kuin seitsemän tekijää sisältävä, mutta siitä jätettiin pois vaikeaksi todettu motivaatiotekijä. Kuuden tekijän malli on vielä lähempänä koulutuksen järjestäjän näkökulmaa kuin seitsemän tekijän malli kartoittaessaan vain koulutuksen sisäisiä ja ulkoisia tekijöitä ja jättäessään oppijoiden ominaisuudet tarkastelun ulkopuolelle. Molemmat ko. mallit osoittautuivat analyyseissa logiikaltaan kelvollisiksi, kuuden tekijän malli rakenteeltaan hieman paremmaksi.

\section{Mallien avulla tunnuslukuja}

Tutkimuksessa kehitetyn koulutuksen rakennemallin avulla voidaan laskea koulutussuunnitelman vaikuttavuusindeksi yksinkertaisesti arvioimalla kunkin seitsemän menestystekijän numeroarvosana (esimerkiksi kouluarvosanoilla 4...10) ja laskemalla hankkeen menestystekijöiden arvosanojen prosenttiosuuksilla punnittu keskiarvo. Vaikuttavuusindeksin avulla on tarkoitus helpottaa koulutushankkeiden vertailua toisiinsa. Oikeiden koulutusaiheiden löytäminenhän osoittautui erääksi suomalaisen henkilöstökoulutuksen kehittämiskohteeksi.

Hyötyjen ja kustannusten suhteita pidetään yleisesti perusteina investointien toteutusta harkittaessa. Koulutushankkeiden markkamääräisiä hyötyjä on hyvin vaikeata arvioida varsinkaan hankkeen suunnitteluvaiheessa, jolloin investoinnin kohtalosta pitäisi päättää. Koulutuskustannukset sen sijaan tiedetään usein markalleen jo suunniteltaessa kurssia tai laajempaakin koulutuskokonaisuutta.

Koulutusinvestointien taloudellista vertailtavuutta voidaan parantaa sellaisella kustannus/ hyöty -analyysilla, jossa markkojen sijaan vaikuttavuusindeksiä käytetään kuvaamaan investoinnin hyötyjä. Koulutushankkeiden vertailussa käytetään sitten apuna vaikuttavuusindeksi- 
en ja kustannusten välisillä suhteilla laskettuja tunnuslukuja.

Sijoitettaessa aineelliseen pääomaan määritetään yleensä investoinnin taloudellinen arvo. Jos henkilöstökoulutuksen vaihtoehtona on esimerkiksi laiteinvestointi, koulutuksellekin on pyrittävä määrittämään vertailun mahdollistamiseksi vaikuttavuusindeksin lisäksi investoinnin taloudellinen arvo. Sen laskeminen ei ole helppoa kaikissa koulutusinvestoinneissa eikä aina edes mahdollista, osin ei tarpeenkaan.

Koulutuksen antamaa taloudellista arvoa voi laskea kuitenkin esimerkiksi laadun paranemisena, tuotoksen lisääntymisenä tai poissaolojen vähenemisenä. Jos jo nämä osoittavat koulutuksen kannattavaksi ei muita kriteereitä tarvitakaan. Monissa tapauksissa myös yleisesti käytettyjen taloudellisten tunnusten kuten ROIn laskeminen on koulutuksessa yhtä mahdollista kuin muissakin investoinneissa.

\section{KOULUTUSVAIKUTUSTEN KOKONAISVALTAINEN ARVIOINTI}

Pelkät taloudelliset tunnusluvut eivät tietystikään voi kertoa edes maksajan näkökulmasta henkilöstökoulutuksen kaikkia vaikutuksia. Henkilöstökoulutuksen monipuolisista vaikutuksista keskusteltaessa puhutaan koulutusvaikutusten kokonaisvaltaisesta arvioinnista. Se voidaan jakaa ennakkoarviointiin ja ns. viivästettyyn arviointiin. Investoinnin suunnitteluvaiheessa tapahtuvassa koulutuksen kokonaisvaltaisessa ennakkoarvioinnissa määritetään harkinnan tueksi hankkeen vaikuttavuusindeksi ja mahdollisesti investoinnin kustannus/hyötysuhde tai taloudellinen arvo. Kokemuksia aiemmista samankaltaisista hankkeista voidaan myös käyttää hyväksi.

Viivästetyssä arvioinnissa uusitaan ennakkoarvioinnissa käytetyt arviot, nyt täsmällisempien tietojen pohjalta, koska niitä saadaan kirjanpidosta "kovina lukuina”. Lisäksi jälkiarvioinnissa hyödynnetään koulutukseen osallistuneiden palautteita, mahdollisesti mitattuja oppimistu- loksia ja käyttäytymismuutoksia sekä koulutuksen vaikutuksia operatiivisiin ja taloudellisiin tunnuslukuihin. Kokonaisvaltaista koulutuksen vaikuttavuutta selvitetään siis $3 \ldots 7$ eri tavalla. Viivästetyn arvioinnin tietoja voi käyttää suunnittelussa hyväksi vertailu- tai ennakkotietoina toteutetuista hankkeista tai uusien hankkeiden pilottiosista, mutta muutoinhan viivästetyn arvioinnin tiedot liittyvät lähinnä "historiankirjoitukseen".

\section{APUA KENTÄN ONGELMIIN}

Suomessa ollaan laajasti yksimielisiä siitä, että menestymme kansainvälisessä kilpailussa vain hyvin koulutetun ja motivoituneen henkilöstön avulla. Tulevaisuudessa ei riitä, että vain osa organisaatiosta on osaavaa ja motivoitunutta. Vaade koskee koko organisaatiota ja kaikkia avoimessa kilpailussa olevia elinkeinoaloja. Jos koulutuksella ja sen pitkäjänteisellä arvioinnilla vaikutetaan mainittujen vaatimusten saavuttamiseen, ollaan varmemmalla pohjalla, kuin esimerkiksi valittaessa toteutettava koulutus vielä nykyisin yleisesti käytetyllä “mutumenetelmällä”.

Pelkistetyn ja helppokäyttöisen koulutuksen arviointimallin kehittäminen tuli entistä ajankohtaisemmaksi, kun henkilöstöasiantuntijoiden määrää on supistettu tuloskuntoon trimmatuissa organisaatioissa ja kun tulosodotukset ovat korkealla. Esimiehet pystyvät muilta kiireiltään keskittymään koulutuksen ongelmiin entistä vähemmän. Kun asiantuntija-apua ei ole käytettävissä, yksinkertaisen mallin käyttö on perusteltua, jos sen avulla koulutuksella saadaan parempia tuloksia kuin ilman mallia. On korostettava, että taloudellisten mittarien antamat arvot ovat päätöksenteossa inhimillisen harkinnan tukena.

Tässä artikkelissa esiteltyä mallia on kokeiltu lähinnä kurssimuotoisen henkilöstökoulutuksen arviointiin. Kurssimuotoisen koulutuksen osuus suomalaisessa henkilöstön kehittämisen kentässä on vähentynyt tunnetuista syistä. Mikäli koulutusta arvioidaan ja kehitetään kriittisesti ja kokonaisvaltaisesti, on kurssimuotoisella kou- 
lutuksella sijansa henkilöstön kehittämismuotona nyt ja tulevaisuudessa. Tutkimuksessa löydetyt koulutuksen menestystekijät ovat siinä määrin yleisiä, että niitä voidaan käyttää henkilöstön kehittämistoiminnan arviointiin kurssimuotoista koulutusta laajemminkin. Toisaalta ne soveltuvat myös ainakin osaan ammatillisen peruskoulutuksen arviointia.

Vähän käytetyissä mittarissa ja malleissa on luonnollisesti kehitettävää. Mm. tuloksellisen koulutuksen menestystekijöiden kartoitusta on syytä toistaa aika ajoin kunnes kehityksen suunta on varmistunut. Mallit toimivat ainakin välineenä liikkeenjohdon ja kouluttajien yhteisen kielen hakemisessa.

Mallia tai sen osia voidaan käyttää esimerkiksi vaihtoehtoisten kurssitarjousten vertailuun tai jo toteutettavaksi päätettyjen koulutussuunnitelmien kehittämiseen ja parantamiseen. Tällöin menestystekijät käsitellään vaihe vaiheelta ja valitaan tuloksellisin vaihtoehto, tai muutetaan suunnitelmaa niiltä osin kuin havaitaan tarvetta. Arvioinnin varmuutta voidaan lisätä tekemällä se yhteistyönä ryhmässä, jossa on koulutuksen tilaajia, opettajia ja tulevia kurssilaisia. Tällaisissa ryhmissähän kurssien sisällötkin yleisesti suunnitellaan. Harjoittelu tekee mestariksi tässäkin lajissa.

Mittaria voi käyttää organisaatiossa tai sen osassa toteutuneen koulutuksen arviointiin. Saatuja tuloksia vertaillaan tavoitteena pidettävän tuloksellisen koulutuksen piirteisiin ja vertailutietoja käytetään koulutuksen kehittämisen pohjana.

Vaikuttavuustutkimus on täyttänyt sille asetetut odotukset, jos henkilöstökoulutuksen tasoa pystytään kohentamaan edellä esitetyillä, yksinkertaisilla keinoilla. Tulevaisuudessa tietämystä voidaan syventää ja ehkä luoda uutta, käytännön tarpeista lähtevää ja työelämää palvelevaa teoriaa. Pyrittäessä tieteen keinoin hyödyttämään käytäntöä on pidettävä mielessä kasvatustieteeseenkin sopiva vanha hokema “paras on hyvän vihollinen”. Tärkeiksi todettuja päämääriä kohti on edettävä pienin askelin.

\section{Erään koulutushankkeen arvioinnista}

\begin{abstract}
Yrityksen koulutustarvekartoituksissa ja johdon arvioissa oli todettu puutteita ihmisten johtamisen taidoissa. Kun puutteita uskottiin voitavan poistaa koulutuksella, ei kuitenkaan omin eväin, kartoitettiin monipuolisesti maassamme tarjolla olevaa koulutustarjontaa. Muutamalta taholta pyydettyjen tarjousten perusteella valittiin sopivimpana ohjelmana tunnetun koulutuksen järjestäjän kaksipäiväinen työseminaari (ei halvin). Sen tavoitteet liittyivät itsetuntemuksen lisääntymiseen, ihmisten johtamiseen liittyvien taitojen paranemiseen, itsetunnon vahvistumiseen, kehittyvän esimiesroolin ymmärtämiseen ja yrityksen johtamiskulttuurin kehittymiseen.
\end{abstract}

Työseminaarin jälkeen työpaikoilla harjoiteltiin seminaarissa käsiteltyjä asioita. Noin puoli vuotta työseminaarin jälkeen seurantapäivänä käsiteltiin seminaareissa sovittuja välitöitä sekä oppien soveltamista edistäneitä ja haitanneita tekijöitä.

\section{Ennakkoarviointi}

Ennen koulutusohjelman valitsemista ennakoitiin koulutusta suunnitelleessa työryhmässä koulutuksesta saatavaa palautetta yrityksen käyttämällä mitta-asteikolla. Tällöin arvioitiin mm. miten koulutus liittyy kohderyhmän työhön, miten motivoituneita osanottajat ovat, minkätasoista koulutus ja opetusmateriaalit ovat, miten esimiehet tukevat annettavaa koulutusta ja miten osanottajat hyödyntävät oppimaansa työssä. 
Ennakkoarvioinnissa päädyttiin siihen, että hankkeen kokonaisarvosana tässä artikkelissa esitetyllä tavalla määritettynä on 8,5 eli 850 pistettä tuhannesta mahdollisesta.

Tarjousten ja koulutustilastojen perusteella tiedettiin koulutuksen kustannukset jo ennakkoon. Yhden oppilaspäivän kustannuksiksi laskettiin $780 \mathrm{mk}$. Pisteen hinnaksi voitiin siis laskea 0,92 mk (780 mk : 850 pistettä). Koulutuksesta saatavaa taloudellista hyötyä ei osattu ennakoida. Työnjohtajien esimiehet ja ryhmä ylempiä toimihenkilöitä oli käynyt kyseisessä koulutuksessa ennen työnjohtoporrasta. Kokemukset heidän koulutuksestaan rohkaisivat laajentamaan koulutusta työnjohtotasoon.

\section{Viivästetty arviointi}

Kysymyksessä oli ensi vaiheessa lähes kolmensadan henkilön koulutushanke. Siksi oli luonnollista, että yrityksessä haluttiin katsoa myöhemminkin, millaista vastinetta lähes miljoonan markan investoinnilla saatiin.

Koulutuksen jälkeen kerättiin koulutuksessa olleilta työnjohtajilta normaalit palautteet. Ne sisälsivät samantyyppisiä tietoja kuin ennakkoarvioinnitkin. Nyt indeksit ja pisteet voitiin laskea pääosin koulutuksessa olleiden henkilöiden todellisuudessa antamien arvosanojen keskiarvoina. Reaktiopalautteet eivät poikenneet ennakoiduista.

Opetettujen asioiden omaksumista ja työkäyttäytymisen muutoksia tutkittiin osanottajille ja heidän esimiehilleen suunnatuilla kyselyillä sekä esimiesten havainnoilla. Valtaosa kysymyksistä testasi opetettujen asioiden soveltamista työssä. Osanottajat vastasivat samoihin kysymyksiin kaksi kertaa, ensimmäisen kerran koulutuksen alussa ja toisen kerran noin puoli vuotta kertausjakson jälkeen (noin vuoden kuluttua ensimmäisestä kyselystä).

Esimiehet vastasivat vain koulutuksen vaikutuksia mittaaviin kysymyksiin, niihinkin ainoastaan kerran, noin puolen vuoden kuluttua alaisten koulutuksesta. Työnjohtajat ja heidän esimie- hensä ilmoittivat koulutuksen vaikuttaneen työkäyttäytymiseen samalla tavalla tavoitteiden mukaisesti. Esimiehet suhtautuivat koulutukseen hieman myönteisemmin kuin työnjohtajat.

Arvioitaessa esimerkkitapauksessa koulutusinvestoinnin taloudellista hyötyä vertailukohteena voitiin pitää yhtä yrityksen osa-aluetta, jossa työnjohtajat eivät heistä riippumattomista syistä osallistuneet kyseiseen koulutukseen. Yleisesti ottaen kaikki yksiköt vastasivat ominaisuuksiltaan toisiaan.

Koulutuskustannukset ilman osanottajien koulutusajan palkkakustannuksia olivat kirjanpidon mukaan 730000 markkaa. Koulutusajan palkkaa ei otettu huomioon, koska yrityksessä ei palkattu työnjohtajille sijaisia koulutuksen ajaksi, vaan koulutuksessa olevien työnjohtajien oletettiin hoitavan kurssiaikana rästiin jäävät tehtävänsä ennakkoon ja koulutuksen jälkeen. Delfi-menetelmällä arvioitiin kulutusvaikutuksen kestävän lineaarisesti alentuen kolme vuotta.

Ennen koulutusta kaikkien tulosyksiköiden operatiiviset tulokset olivat samaa luokkaa. Koulutusta seuraavina kolmena vuonna operatiivisista tilastoista poimitut koulutettujen yksiköiden yhteistulokset olivat investointihetkeen muunnettuina noin 12 miljoonaa markkaa paremmat kuin kouluttamattoman yksikön kolmen vuoden tulokset. Tulosten eron selittäjäksi ei keksitty mitään muuta tekijää kuin kyseinen koulutusohjelma. Tulosten erosta laskettiin kuitenkin varovaisesti vain kolmannes koulutuksesta johtuvaksi, eli 0,73 miljoonan markan koulutuspanoksella arvioitiin saadun 3,75 miljoonan markan hyöty. Nettohyöty oli näin ollen $3,75-0,73=3,02$ miljoonaa markkaa.

Jälkikäteen laskettu investoinnin tuottoaste ROI (3,02 milj. mk: 0,73 milj. mk x 100) osoitti tuotoksi 400 prosenttia eli sijoitus maksoi itsensä takaisin nelinkertaisesti kolmessa vuodessa. Investointien vuotuisena tuottovaatimuksena yhtiössä pidettiin $15-25$ prosenttia.

Kaikki koulutusohjelman vaikuttavuuden ar- 
viot ja mittaukset (vaikuttavuusindeksit, käyttäytymismuutokset, taloudellinen tuotto) osoittivat samansuuntaista tulosta, joten koulutuksen myönteisiä vaikutuksia pidettiin uskottavina. Käsitystä vahvisti se, että aluksi koulutuksesta sivuun jättäytynyt tulosyksikkö otti sen kiireesti ohjelmaansa em. tulosten alettua näkyä yksiköiden operatiivisissa tilastoissa.

\section{Kirjjllisutta}

AHO, T. (1989) Investointilaskelmat. (2. painos) Ekonomia-sarja. Weilin+Göös, Vaasa.

ANON. (1996) Valkoinen kirja koulutuksesta: Opettaminen ja oppiminen - kobti kognitiivista ybteiskuntaa. Euroopan komissio. Luxemburg: Euroopan yhteisöjen virallisten julkaisujen toimisto, 1995.

BRINKENHOFF, R. O. (1991) Achieving Results from Training. Jossey-Bass Publishers, San Francisco.
KANTANEN, U. (1996) Henkilöstökoulutus, sen vaikutukset ja tuloksellisuns yrityksen näkökulmasta. Acta Universitatis Tamperensis. ser A vol. 508.

MONTEAU, P. (1987) Establishing Corporate Evaluation Policy: Cost Versus Benefit. Teoksessa May, S. L., Moore, C. A. \& Zammit, S. J. Evaluating Business and Industry training. Kluwer Academic Publishers, Boston, 197-206.

ROBINSON, D. G. \& ROBINSON, J. C. (1989) Training for Impact. Jossey-Bass Inc. Publishers, San Francisco.

YLI-LUOMA, P. V. J. (1990) Predictors of Moral Reasoning. Uppsala University. IEA Monograph Studies No.14. Almqvist \& Wiksell International, Stockholm.

Kirjoittaja väitteli 25.10.1996 tohtoriksi Tampereen yliopiston kasvatustieteellisessä tiedekunnassa aiheesta Henkilöstökoulutuksen vaikutukset ja tuloksellisuus yrityksennäkökulmasta.

Artikkeli saapui toimitukseen 14.1.1997.Artikkeli hyväksyttiin julkaistavaksi 3.4.1997. 